\title{
Platelet activating factor receptor expression is associated with neuronal apoptosis in an in vivo model of excitotoxicity
}

\author{
Steffany A.L. Bennett ${ }^{1,4}$, Jiahua Chen ${ }^{1}$, Bruce A. Pappas ${ }^{2}$, \\ David C.S. Roberts ${ }^{1}$ and Martin Tenniswood ${ }^{4}$ \\ 1 Institute of Biochemistry, Life Science Research Centre, Carleton University, \\ Ottawa, Ontario, K1S 5B6, Canada \\ 2 Institute of Neuroscience, Carleton University, Ottawa, Ontario, K1S 5B6, \\ Canada \\ ${ }^{3}$ Adirondack Biomedical Research Institute, Lake Placid, New York, 12946, USA \\ ${ }^{4}$ corresponding author: Dr. Steffany A.L. Bennett, Institute of Biochemistry, Life \\ Sciences Research BIdg, Carleton University, 1125 Colonel By Drive, Ottawa, \\ Ontario, K1S 5B6, Canada; Tel: (613) 520-3991; fax: (613) 520-4052; email: \\ stefbenn@ccs.carleton.ca
}

Received 19.2.98; revised 11.6.98; accepted 23.6.98

Edited by M. Israel

\begin{abstract}
Platelet activating factor (PAF), an endogenous proinflammatory agent, mediates neuronal survival, glutamate release, and transcriptional activation following excitotoxin challenge. To determine whether PAF receptor (PAFR) expression is altered during excitotoxicity, changes in PAFR mRNA localization were compared with markers of neuronal apoptosis and reactive gliosis following systemic injection of kainic acid. Data from semi-quantitative RT-PCR, in situ hybridization, DNA fragmentation, cellular morphology analysis, and immunohistochemistry demonstrate that the localization of PAFR $m R N A$ is altered during kainic acid-induced neurodegeneration. While PAFR mRNA is normally exhibited by neurons and microglia in rat hippocampus, expression becomes restricted to apoptotic neurons and to glia involved in phagocytosing apoptotic debris following treatment with excitotoxin. PAFR mRNA is rarely detected in surviving neurons. These data provide the first indication that PAFRexpressing neurons may be preferentially susceptible to excitotoxic challenge.
\end{abstract}

Keywords: platelet activating factor; apoptosis; neurodegeneration; kainic acid; epilepsy; excitotoxicity

Abbreviations: CNS, central nervous system; $B S A$, bovine serum albumin; GAPDH, glyceraldehyde-3-phosphate dehydrogenase; GFAP, glial fibrillary acidic protein; $\mathrm{H} / \mathrm{E}$, hemotoxylin and eosin; PAF, platelet activating factor; PAFR, platelet activating factor receptor; RT-PCR, reverse transcriptase-polymerase chain reaction

\section{Introduction}

In vivo models of excitotoxicity produce a well-defined sequence of neuronal death in brain regions with high levels of glutamate receptors. Following systemic injection of kainic acid, neuronal necrosis is observed in rat hippocampus within hours of excitotoxin administration while animals are still undergoing epileptiform seizures (Ben-Ari, 1983; Lassman et al, 1984; Smeyne et al, 1993; Bennett et al, 1995). The loss of plasma and nuclear membrane integrity and leakage of cytoplasmic and nuclear material into brain parenchyma triggers a cerebral inflammatory response characterized by reactive gliosis and activation of microglia (Bennett et al, 1995; Taniwaki et al, 1996; Boschert et al, 1997). Morphological changes defining neuronal apoptosis appear only after epileptiform activity has subsided and excitotoxin has been cleared from brain tissue. Apoptotic neurons are identified by their pyknotic, condensed, and hyperchromatic appearance, blebbing of extracellular and nuclear membranes, intranucleosomal fragmentation of DNA, and compartmentalization of cytoplasmic and nuclear components into smaller 'apoptotic' bodies without compromise of membrane integrity (Smeyne et al, 1993; Sakhi et al, 1996; Boschert et al, 1997). Comparable kinetics of cell death are observed in experimental models of ischemia/reperfusion and following direct intracerebral injection of glutamate analogs (Dragunow et al, 1994; van Lookeren Campagne et al, 1995; Nitatori et al, 1995; Choi, 1996).

Protracted exposure to proinflammatory ligands is characteristic of a number of clinical conditions linked to excitotoxicity, including Alzheimer's disease, Huntington's disease, ischemia, and epilepsy (Kalaria, 1993; Giulian et al, 1994; Majno and Joris, 1995; Steinberg et al, 1996). How a cerebral inflammatory response affects the kinetics of neuronal loss is not well understood although proinflammatory agents such as platelet activating factor (PAF: 1-O-alkyl-2-acetylglycero-3-phosphocholine) have been directly linked to peripheral pathogenesis. PAF is a proinflammatory phospholipid made up of predominant molecular species $\mathrm{C}_{16} \mathrm{H}_{33}$ and $\mathrm{C}_{18} \mathrm{H}_{35}$ with biological activity at $\mathrm{fM}$ concentrations (Beusenberg et al, 1994). PAF interacts with a $G$ protein-linked receptor protein (PAFR) cloned from guinea pig lung (Honda et al, 1991), rat spleen (Bito et al, 1994), human heart (Sugimoto et al, 1992), HL60 cells (Ye et al, 1991), and U937 cells (Kunz et al, 1992) and expressed at low-levels in central nervous system (CNS) (Bito et al, 1994). PAF regulates peripheral cytokine and inflammatory networks (Bonavida and MenciaHuerta, 1994) with prolonged signal transduction implicated in the pathogenesis of hypotensive shock, bronchial asthma, ulcerative colitis, Crohn's disease, and tumour progression (Sobhani et al, 1992; Yamamoto et al, 1993; Ferraris et al, 1993; Bennett et al, 1993; Graham et al, 1994). In CNS, sustained PAF stimulation is observed during ischemia, encephalitis, meningitis, and human immunodeficiency virus-1 infection (Kumar et al, 1988; Gelbard et al, 1994; Marcheselli and Bazan, 1994). In vitro activation of PAFR in neurons and glia elicits calcium 
transients (Yue et al, 1992), release of arachidonic acid metabolites (Petroni et al, 1994), phosphoinositide turnover (Yue et al, 1992; Petroni et al, 1994), and proto-oncogene expression (Squinto et al, 1989). With respect to excitotoxicity, PAF enhances glutamate release and increases expression of transcriptional factors associated with apoptosis (i.e. c-fos, c-jun) (Bazan et al, 1993; Marcheselli and Bazan, 1994). PAF antagonists attenuate excitotoxic cell death in vitro and protect neurons from ischemic injury in vivo (Braquet et al, 1989; Feurstein et al, 1990). Thus, PAF appears to influence excitotoxic cell loss.

To determine whether pivotal PAF signal transduction molecules are implicated in excitotoxic apoptosis, we examined the distribution of PAFR mRNA in damaged neurons and reactive glia of the rat hippocampus following systemic injection of kainic acid.

\section{Results}

\section{Kainic acid-induced seizures}

Rats were injected with $10 \mathrm{mg} / \mathrm{kg}$ kainic acid. Seizure progression was assessed according to previously published criteria (Mclntyre et al, 1982). Rats exhibited stage 1 'wet-dog shakes' 15-30 min after treatment, stage 2 rearing and weak clonic convulsions $60 \mathrm{~min}$ after injection, stage 3 loss of postural control and increasingly severe convulsions $90 \mathrm{~min}$ after treatment, and stage 4 generalized limbic seizures 120 180 min after excitotoxin administration. Seizures were stopped $5 \mathrm{~h}$ after kainate injection by administration of a sub-anesthetic dose of sodium pentobarbitol $(25 \mathrm{mg} / \mathrm{kg})$.

\section{Reverse transcriptase-polymerase chain reaction (RT-PCR) analysis of PAFR}

A 381 bp fragment of PAFR was amplified from whole brain RNA with appropriate restriction digest characteristics (Figure 1A). Control reactions, carried out in the absence of RNA or RT, failed to produce cDNA demonstrating the specificity PAFR template transcript (Figure 1A). Changes in PAFR expression were standardized against glyceraldehyde-3phosphate dehydrogenase (GAPDH) mRNA expression to establish that alterations in PAFR message, particularly decreases in steady-state mRNA, were not the result of random variations in total RNA template concentration. GAPDH was chosen as an internal standard based on previously published results (Szaflarski et al, 1995). Because the relative abundance of GAPDH mRNA is significantly greater than PAFR in brain, optimal cycling times for PAFR amplification ( 30 cycles) and GAPDH amplification (23 cycles) were determined (date not shown). Based on these results, GAPDH primers were added to ongoing PCR reactions at the onset of cycle 8 . To confirm that PCR amplification fell within a linear range of detection, varying amounts of template RNA were co-amplified using this protocol (Figure 1B). Two $\mu \mathrm{g}$ of template RNA was sufficient to detect both increases and decreases in PAFR and GAPDH mRNA.

Total RNA was isolated from the hippocampal formation of six animals per time point at $0,5,24$, and $168 \mathrm{~h}$ following kainate injection and subjected to RT-PCR analysis.
Southern analysis confirmed the identity of the amplified fragments as PAFR and GAPDH (Figure 1C). The kinetics of PAFR expression were quantitated by ELISA of biotinylated (PAFR) and fluoresceinated (GAPDH) PCR
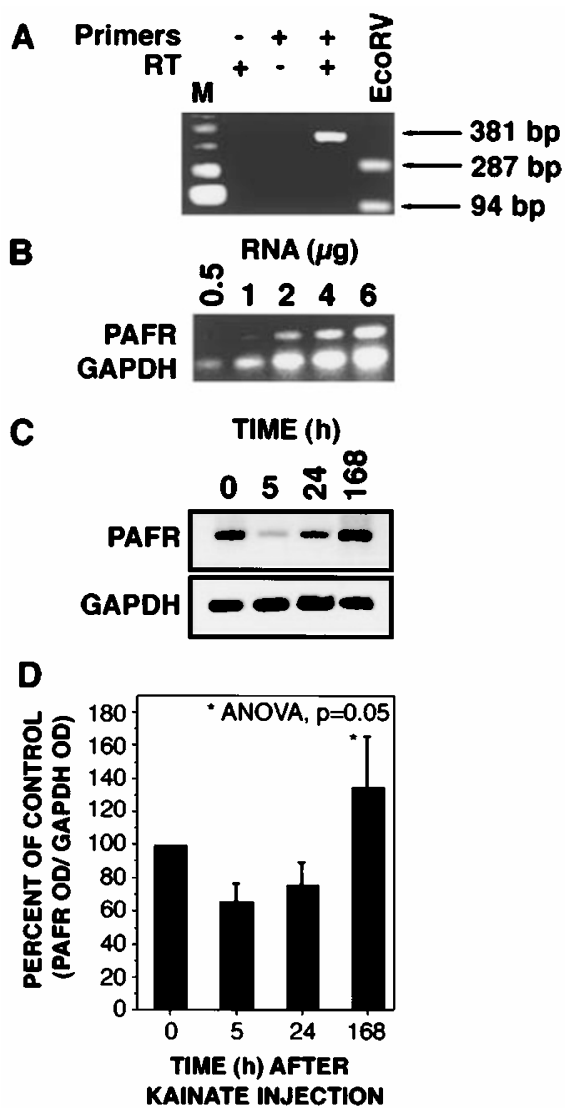

Figure 1 Semi-quantitative RT-PCR analysis of PAFR expression following systemic injection of kainic acid. (A) Total RNA was extracted from whole brain tissue of control animals and RT-PCR performed as described in Materials and Methods. Two $\mu \mathrm{g}$ of total RNA was reverse transcribed in a $20 \mu$ l volume. Ten $\mu$ l of CDNA was PCR amplified. Primers were $5^{\prime}$-biotin-CACTTATAACCGCTACCAGGCAG-3' (forward) and 5'-biotin-AAGACAGTGCAGACCATCCACAG-3' (reverse) defining a $381 \mathrm{bp}$ PAFR fragment. Amplification produced the appropriate PAFR cDNA product with the correct restriction enzyme digest sites. RT-PCR reactions processed in the absence of RNA or primers did not amplify PAFR cDNA. (B) The optimal concentration of template RNA for semiquantitative analyses was established by co-amplifying varying concentrations of rat brain RNA with biotinylated PAFR primers and fluoresceinated GAPDH primers. GAPDH primers were 5'-FITC-TGGTGCTGAGTATGTCGTGGAGT-3' (forward) and 5'-FITC-AGTCTTCTGAGTGGCAGTGATGG-3' (reverse) defining a $292 \mathrm{bp} \mathrm{GAPDH}$ fragment. PCR reactions were carried out at $95^{\circ} \mathrm{C}(30 \mathrm{~s})$, $55^{\circ} \mathrm{C}(90 \mathrm{~s})$ and $72^{\circ} \mathrm{C}(120 \mathrm{~s})$ for 30 cycles (PAFR) and 23 cycles (GAPDH). Two $\mu \mathrm{g}$ of template RNA fell within a linear range of amplification sufficient to detect both increases and decreases in relative mRNA expression. (C) The kinetics of PAFR expression in rat hippocampus at $0,5,24$, and $168 \mathrm{~h}$ after exposure to kainic acid were determined. Total RNA was extracted from dissected hippocampi. The identity of the $381 \mathrm{bp}$ PAFR and $292 \mathrm{bp}$ GAPDH product was confirmed by Southern blotting using a $1 \mathrm{~Kb}$ Notl/Hindll fragment of pCDM8/PAFR and a $1.5 \mathrm{~Kb}$ Pstl fragment of pGAPDH. Blots were probed for PAFR, stripped, and re-probed for GAPDH. (D) Semi-quantitative analysis of relative PAFR expression following kainate-induced seizures. The amount of biotinylated PAFR RT-PCR product was standardized against the amount of co-amplified fluoresceinated GAPDH RT-PCR product by ELISA as described in Materials and Methods. Data represent the mean \pm s.e.m. of six animals per time point and are expressed as the ratio of PAFR to GAPDH expression 
products as described in Materials and Methods. PAFR signal was standardized against GAPDH expression. Relative PAFR expression decreased to $65 \%$ that of control levels at 5 and $24 \mathrm{~h}$ after kainic acid injection (Figure 1D). mRNA levels increased to $135 \%$ that of control at $168 \mathrm{~h}$ after treatment (Figure 1D).

\section{In situ localization of PAFR mRNA}

PAFR expression was examined in more detail by radioactive in situ hybridization at 0,24 and $168 \mathrm{~h}$ after kainic acid administration. In control animals, PAFR mRNA was detected throughout CA pyramidal cell fields of the hippocampal formation and granule cells of the dentate gyrus (Figure 2A). $A$ decrease in the number of PAFR-positive neurons was evident $24 \mathrm{~h}$ after kainic acid injection (Figure 2B). Hybridization was restricted to isolated groups of cells in the CA layers and to crest cells of the dentate gyrus. An increase in PAFR
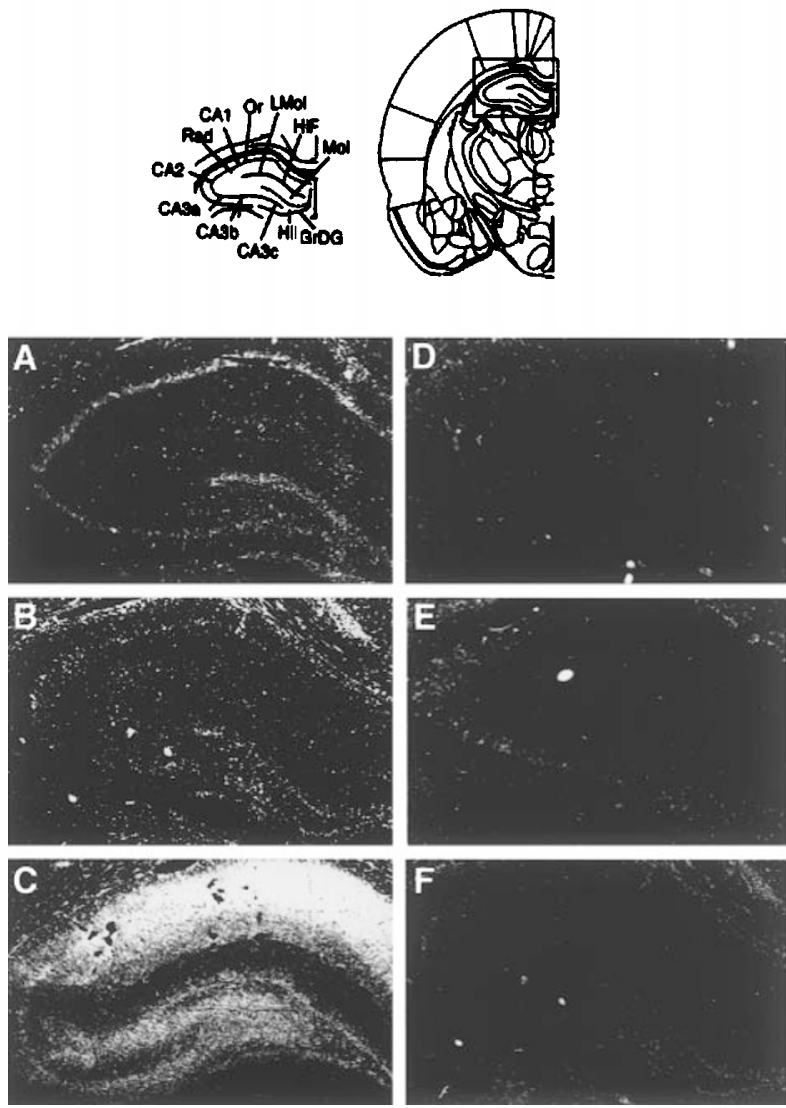

Figure 2 In situ hybridization for PAFR mRNA in hippocampal formation at 0 , 24 , and $168 \mathrm{~h}$ following systemic injection of kainic acid. (A,D) Control (0h). $(B, E) 24 \mathrm{~h}$ after kainate injection. (C,F) $168 \mathrm{~h}$ after kainate injection. Panels $D$, $E$, and $F$ are adjacent sections, pretreated with RNase, and processed for PAFR hybridization, demonstrating the specificity of labeling in A, B, and C. Details are as described in Materials and Methods. Abbreviations are as follows: CA1, CA1 pyramidal cell field; CA2, CA2 pyramidal cell field, CA3a-c, CA3a-c pyramidal cell fields; DG, granule cells of the dentate gyrus; HiF, hilar fissure; Hil, hilus of the dentate gyrus; LMol, lacunosum molecular layer of the hippocampal formation; Mol, molecular layer of the dentate gyrus; Or, oriens layer of the hippocampal formation; Rad, stratum radiatum of the hippocampal formation hybridization was detected $168 \mathrm{~h}$ after kainate administration (Figure 2C). Elevated expression was localized to CA1, $\mathrm{CA} 3 \mathrm{~b}$, and CA3c pyramidal cell fields, the dentate gyrus (particularly in cells immediately adjacent to CA3b and CA3c neurons), and cells of the oriens layer, stratum radiatum, and lacunosum molecular layer.

Non-radioactive in situ hybridization was used to identify cells expressing PAFR. Identification of cell type was based on morphological evaluation. In control tissue, mRNA was detected in pyramidal and granule neurons, microglia, vascular endothelial cells, and ependymal cells lining cerebral ventricles (Figure 3A, G and $H$ ). By $24 \mathrm{~h}$ after kainic acid injection, a reduction in both the intensity of label and in the number of PAFR-expressing neurons was observed (Figure 3B). PAFR-positive neurons were localized in discrete groups primarily in CA1, CA3, and the hilar region of the dentate gyrus (Figure 3B). Some cells were surrounded by PAFR-expressing microglia and astrocytes (data not shown). By $168 \mathrm{~h}$ after kainate administration, PAFR mRNA was primarily localized to activated astrocytes and microglia infiltrating the CA1 and CA3 pyramidal cell fields, the oriens layer, and the stratum radiatum (Figure $3 \mathrm{C}$ ). This shift in localization from neurons to glia corresponds with the increase in PAFR mRNA observed $168 \mathrm{~h}$ after treatment by RT-PCR and radioactive in situ hybridization. Non-radioactive in situ analysis demonstrates that the elevated expression is due to an increase in the overall number of PAFR-expressing glia localized to hippocampus and not to increased transcription given that hybridization is detected in multiple glia but at low levels (Figure 3C).

\section{Excitotoxic apoptosis}

Apoptosis was identified at $0 \mathrm{~h}, 24 \mathrm{~h}$, and $168 \mathrm{~h}$ after kainate injection on the basis of both hemotoxylin and eosin $(H / E)$ morphology and TUNEL as described in (Bennett et al, 1998). In control tissue, apoptotic characteristics were detected consistently in some ependymal cells and cells of the choroid plexus. Apoptotic neurons were observed rarely (approximately three cells per $10 \mu \mathrm{m}$ coronal section). Necrotic neurons were not detected. Systemic treatment with kainic acid resulted in substantial cell loss in the hippocampus. Neuronal apoptosis (Figure $3 \mathrm{I}$ ) and necrotic debris was observed $24 \mathrm{~h}$ after treatment in pyramidal cells of CA3a, $\mathrm{CA} 3 \mathrm{~b}, \mathrm{CA} 3 \mathrm{c}$ and the lateral reaches of CA1. Crest cells of the dentate gyrus and neurons in the ventral reaches of the superior limb and dorsal reaches of the inferior limb of the dentate gyrus (i.e. in close proximity to CA3c neurons) demonstrated apoptotic characteristics. Dentate granule cells outside of thse regions were spared. Astrocytes and microglia were seen infiltrating damaged tissue. Glia proximal to neurons exhibiting DNA damage appeared morphologically to be involved in phagocytosis (data not shown).

It should be noted that TUNEL-positive neurons were more numerous than cells identified on the basis of $\mathrm{H} / \mathrm{E}$ staining aberrations. In the hippocampal formation, sporadic interneurons in the stratum radiatum, lacunosum molecular, and molecular layer of the dentate gyrus as well as cells within the oriens layer immediately surrounding damaged 

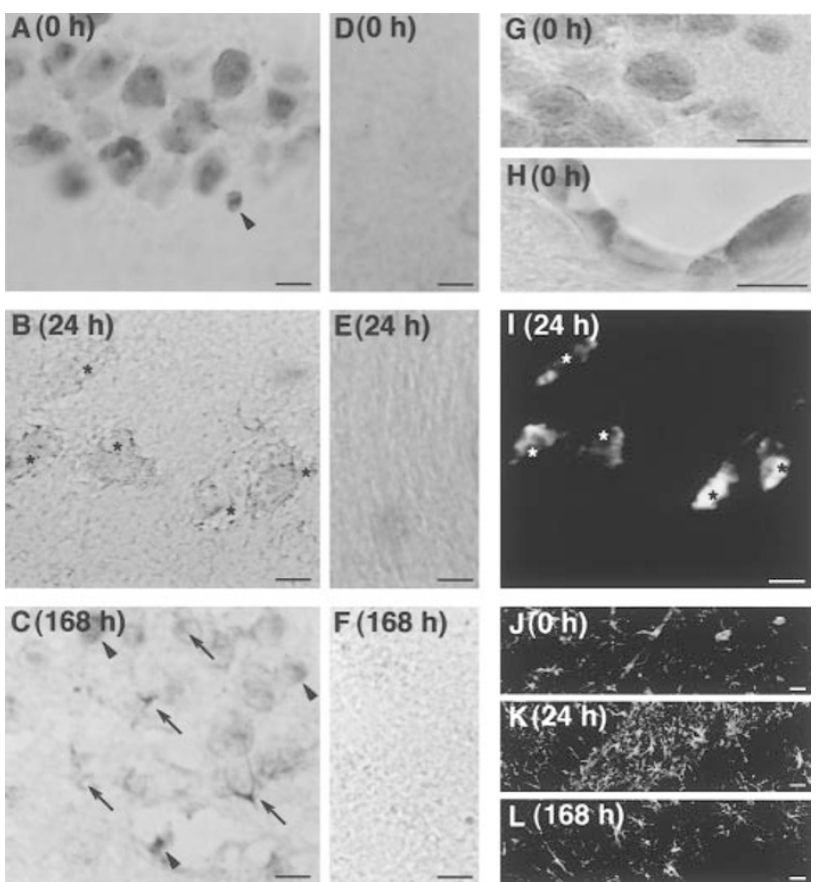

Figure 3 Cellular localization of changes in PAFR expression following systemic injection of kainic acid. All photomicrographs are of CA3 pyramidal cell field except panel $\mathrm{G}$ (dentate gyrus) and panel $\mathrm{H}$ (third ventricle). (A-H) PAFR in situ hybridization. (D, E, and F) are adjacent sections, pretreated with RNase, and processed for PAFR hybridization, demonstrating the specificity of labeling in (A, B, and C). (I) TUNEL performed on tissue presented in (B) following PAFR in situ hybridization (double-label). Asterisks in panel $B$ and I indicate alignment of photomicrographs. (J-L) GFAP-labeled astrocytes. Details are as described in Materials and Methods. In control $(0 \mathrm{~h})$ sections, PAFR $m R N A$ is detected in pyramidal neurons $(A)$ and microglia (arrowhead in $A$ ), in granule cells of the dentate gyrus $(G)$, and in ependymal cells lining ventricular walls $(\mathrm{H})$. By $24 \mathrm{~h}$ after kainate injection, PAFR mRNA is detected almost exclusively in apoptotic neurons double-labeled with TUNEL (B and I). Note that the level of mRNA expressed by dying neurons (B) is less than that expressed by healthy cells in untreated animals (A). Non-apoptotic neurons in degenerating pyramidal cell fields do not express PAFR mRNA (B). By $168 \mathrm{~h}$ after treatment, low levels of PAFR transcript are rarely detected in surviving pyramidal neurons $(\mathrm{C})$. A marked increase in the number of PAFR-expressing astrocytes (arrows in C) and microglia (arrowheads in C) infiltrating pyramidal cell fields is observed. This enhanced frequency of PAFR-positive glia cannot be attributed to an overall increase in reactive gliosis $168 \mathrm{~h}$ after excitotoxic insult given that labeling of reactive astrocytes with GFAP peaks at $24 \mathrm{~h}$ and is reduced $168 \mathrm{~h}$ after kainate injection (J-L). Scale bar, $20 \mu \mathrm{m}$
CA1 pyramidal neurons were consistently TUNEL-reactive. These data are in keeping with enhanced sensitivity of the in situ technique for detecting very early nuclear changes (Gavrieli et al, 1992). However, three notable exceptions in regions outside of the hippocampal formation emphasize the difficulty in differentiating necrotic from apoptotic cell death on the basis of TUNEL alone. Neurons in the amygdaloid nuclei, the ventromedial thalamus, and the medial regions of the ventrolateral thalamus were TUNELpositive. Close examination of $\mathrm{H} / \mathrm{E}$ stained sections demonstrated dense, ubiquitous eosinophilic staining of cell cytoplasm with hemotoxylin-impregnated nuclei indicative of a necrotic rather than an apoptotic process (data not shown). These data underlie the difficulty in relying exclusively on the TUNEL reaction to identify apoptosis in cell systems exhibiting complex temporal patterns of both apoptotic and necrotic death given the capacity of the technique to detect apoptotic DNA fragmentation, late-stage necrotic DNA destruction, and transient DNA repair. In the present study, only those brain regions exhibiting both TUNEL reactivity and $\mathrm{H} / \mathrm{E}$ indices of active cell death were characterized as apoptotic.

Cell loss was quantified at 0,24 , and $168 \mathrm{~h}$ in CA3c pyramidal neurons (Table 1). A $46 \%$ reduction in cell number was observed $24 \mathrm{~h}$ after treatment compared to cell density in control animals. An additional $13 \%$ reduction was apparent $168 \mathrm{~h}$ after treatment. This $13 \%$ decrease could be accounted for by the loss of apoptotic neurons detected $24 \mathrm{~h}$ after kainate injection (Table 1 ).

\section{PAFR expression and neuronal apoptosis}

In control animals, PAFR was detected in healthy neurons. By $24 \mathrm{~h}$ afer kainate administration, PAFR expression was restricted either to neurons undergoing apoptosis or to glia located in close proximity to apoptotic debris. Double-labeling for PAFR in situ hybridization and TUNEL is depicted in Figure $3 \mathrm{~B}$ and $\mathrm{I}$. Expression in undamaged neurons was very low or absent. By $168 \mathrm{~h}$ after treatment, neuronal labeling was replaced by extensive glial expression in $\mathrm{CA} 1$ and $\mathrm{CA} 3$ pyramidal fields (Figures $2 \mathrm{C}$ and $3 \mathrm{C}$ ). Thus, the expression of PAFR was seen to shift from healthy cells in control animals, to apoptotic neurons $24 \mathrm{~h}$ after systemic injection of kainic

Table 1 Cell number, PAFR expression, and apoptosis in CA3c pyramidal neurons following systemic injection with kainic acid

\begin{tabular}{|c|c|c|c|c|c|c|}
\hline \multirow[t]{2}{*}{$\begin{array}{l}\text { Time }(\mathrm{h}) \\
\text { after kainate } \\
\text { injection } \\
\end{array}$} & \multicolumn{2}{|c|}{$\begin{array}{l}\text { Total number } \\
\text { of neurons }\end{array}$} & \multicolumn{2}{|c|}{$\begin{array}{c}\text { Number of } \\
\text { PAFR-expressing } \\
\text { neurons }^{\text {b }}\end{array}$} & \multicolumn{2}{|c|}{$\begin{array}{c}\text { Number of neurons } \\
\text { exhibiting DNA } \\
\text { strand breaks }^{c}\end{array}$} \\
\hline & Mean \pm S.E.M. & $\begin{array}{c}\% \text { of control } \\
(0 \mathrm{~h})\end{array}$ & Mean \pm S.E.M. & $\begin{array}{l}\% \text { of existing } \\
\text { cell number }\end{array}$ & Mean \pm S.E.M. & $\begin{array}{l}\% \text { of existing } \\
\text { cell number }\end{array}$ \\
\hline $\begin{array}{l}0 \\
24 \\
168\end{array}$ & $\begin{array}{r}136+8 \\
74+3 \\
56+4\end{array}$ & $\begin{array}{r}100 \\
54 \\
41\end{array}$ & $\begin{array}{r}82+6 \\
27+2 \\
7+2\end{array}$ & $\begin{array}{l}60 \\
36 \\
12\end{array}$ & $\begin{array}{c}0.3+0.3 \\
24+1 \\
0.7+0.7\end{array}$ & $\begin{array}{r}0.2 \\
33 \\
1\end{array}$ \\
\hline
\end{tabular}

aThe total number of neurons in the CA3c pyramidal cell field was counted in replicate H/E-stained adjacent coronal sections from three animals per time point. Healthy neurons and cells exhibiting morphological indices of apoptosis were included in counts. Necrotic debris was not quantified. ${ }^{\mathrm{b}}$ The number of PAFR-expressing cells was quantified in replicate adjacent sections processed for non-radioactive in situ hybridization from three animals per time point. The number of PAFR-positive glia was not recorded. 'Sections processed for in situ hybridization were double-labeled with TUNEL and the number of neurons exhibiting DNA strand breaks was quantified. Data represent mean+S.E.M. Details are as described in Materials and Methods 
acid, to activated glia $168 \mathrm{~h}$ after treatment. This shift corresponded to a $59 \%$ reduction in the total number of CA3c pyramidal neurons; a loss that could be accounted for by the 91\% reduction in PAFR-expressing neurons, a discrete subpopulation of neurons in the pyramidal cell fields (Table 1). If this decrease in PAFR-positive neurons was simply due to overall cell loss, then approximately 44 of the remaining 74 neurons $(60 \%)$ at $24 \mathrm{~h}$ and 33 of the remaining 56 neurons $(60 \%)$ at $168 \mathrm{~h}$ should have exhibited PAFR mRNA. Instead, only $36 \%$ of neurons exhibited transcript at $24 \mathrm{~h}$ and $12 \%$ of remaining pyramidal cells expressed PAFR message at $168 \mathrm{~h}$. Each of these remaining PAFR-expressing neurons exhibited morphological or biochemical indices of neuronal apoptosis (Figure 3B and I and Table 1). These data indicate selective loss of PAFR mRNA-positive neurons and/or selective downregulation of PAFR mRNA in surviving neurons.

\section{Reactive gliosis}

The kinetics of reactive gliosis were examined to establish whether detection of PAFR mRNA in glia at $168 \mathrm{~h}$ was due to an increase in the overall number of proliferating astrocytes and microglia at this time point or reflects the specific expression of PAFR transcript by glia $168 \mathrm{~h}$ after kainic acid injection. Reactive gliosis was assessed by glial fibrillary acidic protein (GFAP) immunoreactivity (Figure 3J, K and L). We have previously demonstrated that increases in GFAP immunoreactivity are observed $5 \mathrm{~h}$ after kainic acid administration, with maximal gliosis detected $24 \mathrm{~h}$ after seizure induction, and a return to near-normal levels observed by $168 \mathrm{~h}$ (Bennett et al, 1995). Consistent with these data, GFAP-immunoreactive glia were noted in control sections at low numbers throughout hippocampus with preferential localization around blood vessels and ventricular walls (Figure 3J). Maximal reactive gliosis was detected $24 \mathrm{~h}$ after treatment within interneuronal layers of the hippocampal formation with pronounced accumulation in the lacunosum molecular layer and in the hilus of the dentate gyrus. Astrocytic process could be seen infiltrating CA pyramidal cell fields and dentate gyrus granular cells (Figure $3 \mathrm{~K}$ ). Morphological indications of glia phagocytosing both apoptotic bodies and necrotic debris could be observed in GFAP/ TUNEL double-labeled sections and by $\mathrm{H} / \mathrm{E}$ evaluation (data not shown). By $168 \mathrm{~h}$ after treatment, the number of glia infiltrating damaged hippocampus was reduced compared to earlier time points but elevated compared to control levels. GFAP-immunoreactive cells were restricted to the oriens and radiatum cell layers with processes extending into the pyramidal cell field, to the hippocampal hilus, and to cells immediately ventral to the dentate gyrus. Only GFAP-labelled glia at $168 \mathrm{~h}$ exhibited enhanced PAFR expression indicating that detection of astrocytic transcript was not simply the result of enhanced glial numbers normally expressing PAFR but represents a specific induction of PAFR message in proliferating astrocytes at this time point (Figure $3 \mathrm{C}$ and $3 \mathrm{~L}$ ).

\section{Discussion}

Sustained increases in the regional levels of the proinflammatory autacoid PAF have been demonstrated in a number of in vivo excitotoxic disorders and PAF antagonists have been shown to reduce ischemia/reperfusion cell loss while protecting neurons from glutamate toxicity in vitro (Braquet et al, 1989; Feurstein et al, 1990; Marcheselli and Bazan, 1994; Gelbard et al, 1994). To determine whether pivotal PAF signal transduction molecules are modulated during neuronal apoptosis, we analyzed changes in PAFR expression following systemic injection of kainic acid. Our results indicate that PAFR mRNA, normally expressed by a subpopulation of healthy hippocampal neurons and microglia, becomes restricted to neurons undergoing apoptosis and to glia involved in phagocytosing apoptotic debris subsequent to an excitotoxic challenge. Our data also suggest that $91 \%$ of all PAFR-expressing CA3 pyramidal cells apparently die or reduce PAFR mRNA levels within $168 \mathrm{~h}$ of treatment with kainic acid. These data provide the first indication that PAFR expression is modulated during excitotoxicity and leads to speculation that PAFR-expressing cells may be more susceptible to delayed excitotoxic apoptosis in vivo.

\section{Normal PAFR expression in healthy brain tissue}

PAFR transcript in human and rodent brain tissue has been demonstrated by RT-PCR analysis, Northern analysis, and in situ hybridization (Bito et al, 1994; Mori et al, 1996). Ligand binding studies indicate a maximum density of PAF binding sites in the cortex (posterior and neocortex), hippocampus and cerebellum; a lower density in the striatum and hypothalamus; and minimal radioligand labeling in thalamic nuclei (Bito et al, 1992; Domingo et al, 1994). Our data confirm that PAFR mRNA is expressed in the hippocampal formation. In situ localization of transcript indicates that PAFR is expressed primarily by a subpopulation of hippocampal neurons and microglia. Hybridization to nerve cells is consistent with pharmacological localization of PAF binding sites to primary neurons in vitro (Bito et al, 1992) and subcellular localization of $\left[{ }^{3} \mathrm{H}\right] \mathrm{PAF}$ binding to presynaptic nerve terminals, intracellular membranes, and microsomes in cultured cells (Squinto et al, 1989; Marcheselli and Bazan, 1993).

\section{Changes in PAFR expression during acute and chronic excitotoxicity}

The time-course of PAFR cellular redistribution parallels the known genetics of acute and chronic neuropathology following kainate-induced epileptiform seizure (Ben-Ari, 1983; Lassman et al, 1984; Bennett et al, 1995). Acute neuropathology is observed $0-12 \mathrm{~h}$ after kainic acid administration and is characterized by prolonged neuronal depolarization, sustained increases in the expression of immediate early gene products (c-fos, c-jun, zif-268), marked reactive gliosis, and a breakdown in blood-brain barrier function (Ben-Ari, 1983; Lassman et al, 1984; Bennett et al, 1995). Cell loss is primarily necrotic in nature and is evident in pyramidal neurons of the hippocampal formation and cells of the entorhinal and piriform cortices and amygdaloid nuclei (Pollard et al, 1994). Our data indicate that PAFR mRNA expression is reduced during this time period. This finding is consistent with the immediate reduction in $\left[{ }^{3} \mathrm{H}\right] \mathrm{PAF}$ binding 
sites observed following other excitotoxic insults (Domingo et al, 1994).

Chronic neuropathology is elicited $24-168 \mathrm{~h}$ after kainate treatment and occurs in the absence of continued glutaminergic stimulation. Neurodegeneration is characterized by a renewed increase in c-fos transcriptional activation and delayed neuronal apoptosis in c-fosexpressing cells within the hippocampal formation (Pollard et al, 1994). Blood-brain barrier integrity is restored (Bennett et al, 1995). Reactive gliosis peaks $24 \mathrm{~h}$ after excitotoxin exposure (Bennett et al, 1995). Our data indicate that, during this time period, PAFR expression is restricted to apoptotic neurons and to a specific subpopulation of glia involved in phagocytosis of apoptotic debris. We also demonstrate that the percentage of PAFRexpressing CA3c neurons at $24(36 \%)$ and $168 \mathrm{~h}(12 \%)$ after treatment with excitotoxin is substantially less than that observed in control tissue $(60 \%)$. Systemic injection of kainic acid results in a $59 \%$ reduction in the average number of $\mathrm{CA} 3 \mathrm{c}$ neurons. This reduction correlates with the almost complete loss (91\%) of PAFR-positive CA3c neurons. Thus, PAFR expression may be specifically down-regulated in neurons destined to survive kainate toxicity or PAFR-expressing neurons are preferentially susceptible to excitotoxic challenge.

\section{Protracted exposure to proinflammatory agents may influence subsequent neuronal fate}

In support of the latter hypothesis, the kinetics of PAFR mRNA changes closely parallel previous reports of the redistribution of PAF ligand following epileptic seizure and ischemic insult (Kumar et al, 1988; Marcheselli and Bazan, 1994). This correlation suggests that PAF synthesis and PAFR expression are simultaneously present in degenerating tissue during excitoxicity. Expression of PAFR by apoptotic neurons at $24 \mathrm{~h}$ after kainate injection and the redistribution of PAFR mRNA to apoptosis-activated glia at $168 \mathrm{~h}$ after treatment provides circumstantial support for the idea that PAF receptor/ligand interaction is involved in mediating delayed neuronal apoptosis observed after excitotoxin challenge and may be responsible for directing the subsequent clearance of apoptotic debris from damaged tissue. PAF has already been shown to induce expression of transcription factors associated with neuronal apoptosis following exposure to excitotoxins through interaction with high affinity intracellular PAF binding sites (Marcheselli and Bazan, 1994). Our data are also consistent with reports that prolonged exposure to PAF in vitro elicits apoptosis in immature thymocytes (El Azzouzi et al, 1993), triggers cell death in neurons (Kornecki and Ehrlich, 1988; Lustig et al, 1992; Gelbard et al, 1994), and activates astrocytes (Brodie, 1994) in receptor-mediated fashion. While a role for PAF in neuronal apoptosis has yet to be established, definitive evidence has been presented that administration of PAF antagonists attenuates excitotoxic cell death in vivo (Braquet et al, 1989; Doly et al, 1993). These data lead us to speculate that the lack of PAFR transcription in neurons destined to survive prolonged exposure to kainic acid and the localization of mRNA to apoptotic neurons and activated glia infiltrating apoptotic tissue may reflect an endogenous program in CNS designed to promote cell death in (and target glia to) irreversibly damaged cells.

\section{Relevance to in vitro excitotoxicity}

The kinetics of excitotoxic cell death have been well-defined in experimental models of in vivo neurodegeneration. Protracted stimulation of excitatory neurotransmitter receptors induces immediate neuronal necrosis and delayed neuronal apoptosis (Smeyne et al, 1993; Pollard et al, 1994; Portera-Cailliau et al, 1995). However, while cultured neurons undergo rapid DNA fragmentation following treated with glutaminergic agents, cells do not consistently exhibit the morphological characteristics of apoptosis in in vitro cell death paradigms (Dessi et al, 1993; Ikeda et al, 1996). Delayed neuronal apoptosis following ligand removal is rarely observed in glutamatetreated cultures. In vivo and in vitro models of cell death differ in that neurons subjected to excitotoxic challenge in vivo are coincidentally exposed to high concentrations of proinflammatory agents. This exposure is also implicated in a number of clinical neurodegenerative conditions such as Alzheimer's disease, Huntington's disease, ischemia, and epilepsy (Kalaria, 1993; Giulian et al, 1994; Majno and Joris, 1995; Steinberg et al, 1996). What role do proinflammatory agents play in mediating excitotoxic cell loss? Our data raise the intriguing possibility that neurons expressing pivotal proinflammatory signal transduction molecules (i.e. PAFR) may be more likely to undergo delayed excitotoxic apoptosis. Thus, we speculate that coincident sustained exposure to excitatory neurotransmitter and proinflammatory ligands may precipitate an apoptotic cascade in damaged neurons. While specific PAFR antibodies are not currently available, analysis of PAFR protein during excitotoxicity will be required to substantiate this conclusion.

\section{Summary}

PAFR transcript is primarily expressed in vivo by neurons and microglia in healthy tissue. Expression is restricted to apoptotic neurons and to activated glia targeting apoptotic debris following excitotoxic challenge. These data implicate PAF in neuronal apoptosis and support the hypothesis that endogenous proinflammatory agents may play a role in the etiology of excitotoxic cell loss. We suggest that PAFR belongs to a family of proinflammatory mediators associated with excitotoxic and ischemic damage, including inducible nitric oxide synthase and cyclooxygenase-2. These proinflammatory agents may potentially modulate neuronal fate and mediate the cerebral phagocytic response to neuronal apoptosis.

\section{Materials and Methods}

\section{Induction of epileptiform seizures}

Status epilepticus was induced in 24 adult male Wistar rats (Charles River) by intraperitoneal injections of $10 \mathrm{mg} / \mathrm{kg}$ kainic acid (Sigma). Control rats were untreated littermates $(n=6)$. Animals weighed between $300-400 \mathrm{~g}$ at the time of injection. Rats were monitored 
for $5 \mathrm{~h}$ following drug administration and behaviour was rated according to (McIntyre et al, 1982): $0=$ normal activity, $1=$ =increased frequency of 'freezing' and 'wet-dog shakes', 2=weak clonic convulsions with rearing, $3=$ increasingly severe convulsions with loss of postural control, $4=$ generalized limbic seizures, and $5=$ severe limbic seizures with respiratory difficulty. Animals were injected with a sub-anesthetic dose of sodium pentobarbitol $(25 \mathrm{mg} / \mathrm{kg})$ after underoing $2 \mathrm{~h}$ of stage 4 seizures (approximately $5 \mathrm{~h}$ post kainate injection). We have previously demonstrated that this protocol is sufficient to induce delayed neuronal loss while minimizing the amount of time animals are required to undergo epileptiform activity (Bennett et al, 1995). Food and water intake was monitored closely over the following $48 \mathrm{~h}$ to ensure recovery. All manipulations were performed in compliance with approved institutional protocols and according to the strict ethical guidelines for animal experimentation established by the Medical Research Council (Canada) and National Institute of Health (USA).

Rats were deeply anesthetized with sodium pentobarbital at 0, 5, 24 , or $168 \mathrm{~h}$ after kainate injection and euthanized by decapitation ( $n=6 /$ time period). Brains were rapidly removed and dissected down the midline. The hippocampal formation was removed from one hemisphere and total cellular RNA was isolated using TriReagent (Molecular Research Center) according to the protocol provided by the manufacturer. Coronal sections, $10 \mu \mathrm{m}$ in thickness, were cryostat cut from the other hemisphere and thaw-mounted on sterile gelatin-coated microscope slides. Sections were post-fixed for $30 \mathrm{~min}$ in $4 \%$ paraformaldehyde in $100 \mathrm{mM}$ phosphate-buffered saline (PBS: $100 \mathrm{mM}$ sodium phosphate buffer pH 7.2, $154 \mathrm{mM} \mathrm{NaCl}$ ).

\section{Semi-quantitative RT-PCR analysis of PAFR transcripts}

Template RNA was random-primed with $10 \mathrm{pmol} \mathrm{pdN}_{6}$ (Life Science Technologies). RNA and primer were heated for $10 \mathrm{~min}$ at $70^{\circ} \mathrm{C}$. dNTPs (0.125 mM each, Promega), dithiothrietol (DTT: $10 \mathrm{mM}$ ), $1 \times$ RT buffer (Life Sciences Technologies), and superscript RT (200 U; Life Sciences Technologies) were added. Reactions were incubated at $25^{\circ} \mathrm{C}$ for $10 \mathrm{~min}, 42^{\circ} \mathrm{C}$ for $1 \mathrm{~h}$, and $50^{\circ} \mathrm{C}$ for $30 \mathrm{~min}$. Two $\mu l$ of the RT reaction mix was PCR amplified with hot-start in the presence of dNTPs ( $0.3 \mathrm{mM}$ each), $1 \times \mathrm{PCR}$ buffer (Life Sciences Technologies), $2.5 \mathrm{U}$ DNA Taq polymerase (Life Sciences Technologies), 20 pmol PAFR primers, and $10 \mathrm{pmol}$ GAPDH primers. The reaction mixture was denatured at $95^{\circ} \mathrm{C}$ for $30 \mathrm{~s}$, annealed at $55^{\circ} \mathrm{C}$ for $90 \mathrm{~s}$, and extended at $72^{\circ} \mathrm{C}$ for $120 \mathrm{~s}$. Samples were co-amplified for both PAFR and rat GAPDH. PAFR priming occurred over 30 cycles. GAPDH primers were added at the onset of cycle 8 and amplified over the remaining 23 cycles. PAFR primer sequences were $5^{\prime}-C A C T$ T A T A A C C G C T A C C A G G C A G-3' (forward) and 5'AAGACAGTGCAGACCATCCACAG- $3^{\prime}$ (reverse), defining a $381 \mathrm{bp}$ fragment of the rat spleen cDNA (Bito et al, 1994). PAFR primers were biotinylated at the $5^{\prime}$ end. GAPDH primer sequences were $5^{\prime}$ TGGTGCTGAGTATGTCGTGGAGT-3' (forward) and 5'-AGTCTTCTGAGTGGCAGTGATGG-3' (reverse) defining a 292 bp fragment of the rat GAPDH cDNA (Piechaczyk et al, 1984). GAPDH primers were fluoresceinated at the $5^{\prime}$ end. Labeled primers were synthesized by the Molecular Biology Core Facility at Adirondack Biomedical Research Institute. PAFR PCR products were digested with EcoRV to demonstrate appropriate restriction enzyme digestion characteristics.

PCR products were size-fractionated by electrophoresis on a 1.2\% (w/v) agarose gel, transferred to Hybond $\mathrm{N}$ membrane (Amersham), baked at $80^{\circ} \mathrm{C}$ for $20 \mathrm{~min}$, and irradiated with ultraviolet light for $2 \mathrm{~min}$ for Southern analysis. Membranes were washed for $30 \mathrm{~min}$ at $65^{\circ} \mathrm{C}$ in $2 \times$ SSC wash solution $((1 \times$ SSC: $150 \mathrm{mM} \mathrm{NaCl}, 15 \mathrm{mM}$ sodium citrate) $/ 0.1 \% \mathrm{SDS}$ ), prehybridized for $1 \mathrm{~h}$ at $65^{\circ} \mathrm{C}$ in pre-hybridization solution $(50 \mu \mathrm{g} / \mathrm{ml}$ sonicated salmon DNA, $6 \times$ SSC, $5 \times$ modified Denhardt's solution $(0.1 \%$ ficoll, $0.1 \%$ polyvinylpyrolidone, $0.1 \%$ bovine serum albumin, $50 \mu \mathrm{M}$ trans-1,2,-diamine-cyclohexaneNNN'N',-tetraacetic acid), $0.5 \%$ SDS, $50 \mathrm{mM}$ sodium phosphate) and hybridized for $18 \mathrm{~h}$ at $65^{\circ} \mathrm{C}$ in fresh pre-hybridization solution containing $5 \%$ dextran sulfate and a denatured ${ }^{32} \mathrm{P}$-labeled $1 \mathrm{~Kb}$ Notl/ Hindll fragment of the human leukocyte PAFR gene in pCDM8/PAFR (Kunz et al, 1992) kindly provided by Dr. N. Gerard, Harvard Medical School, Boston MA or a ${ }^{32} \mathrm{P}$-labeled $1.5 \mathrm{~Kb}$ Pstl fragment of the rat GAPDH gene in pGAPDH (Piechaczyk et al, 1984). The cDNA insert was purified from agarose using the Qiaex II Agarose Gel Extraction kit (Qiagen) and multiprimed using a random primer labeling kit (Pharmacia) according to the protocols provided by the manufacturers. Following hybridization, membranes were washed twice in wash solution for $15 \mathrm{~min}$ at $65^{\circ} \mathrm{C}$ and twice in high stringency solution $(0.16 \times$ SSC, $10 \mathrm{mM}$ Na Citrate, $0.1 \%$ SDS $)$. Membranes were airdried and exposed to X-ray film (Kodak) for $48 \mathrm{~h}$ at $-70^{\circ} \mathrm{C}$. Blots were probed for PAFR, stripped, and re-probed for GAPDH.

Semi-quantitative analysis was performed by ELISA of biotinylated and fluoresceinated RT-PCR products from six animals per time point processed in duplicate. Biotinylated (PAFR) and fluoresceinated (GAPDH) RT-PCR products were amplified simultaneously in the same reaction. Oligonucleotide primers were separated from PCR product by centrifugation through a $500 \mu \mathrm{l}$ Sephacryl S-300 (Pharmacia) column pre-equilibrated with $1 \times$ PCR buffer. PAFR and GAPDH amplicons were immobilized on 96 well ELISA plates coated with anti-DNA primary antibody (1:1000; Boehringer Mannheim) in $10 \mathrm{mM}$ PBS, pH 7.5 containing $0.05 \% \mathrm{NaN}_{3}$ and blocked with $170 \mathrm{mM}$ boric acid $\mathrm{pH} 8.5,120 \mathrm{mM} \mathrm{NaCl}, 0.05 \%$ Tween-20, $0.2 \%$ bovine serum albumin (BSA), $0.05 \% \mathrm{NaN}_{3}$. Products were detected by reaction with extravidin-peroxidase (1:10 000; Sigma) and alkaline phosphatase anti-FITC (1:33; Boehringer Mannheim). Wells were incubated with $50 \mu \mathrm{l}$ peroxidase blue substrate (Boehringer Mannheim) according to the protocol provided by the manufacturer. Absorbance was read at $450 \mathrm{~nm}$. Wells were washed repeatedly, incubated with p-nitrophenylphosphate (Boehringer Mannheim) according to the protocol provided by the manufacturer, and absorbance read at $405 \mathrm{~nm}$. In duplicate reactions, $p$-nitrophenylphosphate absorbance was determined before peroxidase blue absorbance. PAFR (peroxidase blue) optical density was standardized against GAPDH (p-nitrophenylphosphate) optical density to ensure that changes in PAFR signal accurately reflected changes in mRNA expression and were not the result of unequal template concentration or gel-loading error.

\section{In situ hybridization}

In situ hybridization was performed using a Notl/Hindll fragment of the human leukocyte PAFR gene (Kunz et al, 1992). The fragment was either multiprimed with $\left[\alpha^{35}\right.$ S $]$ dCTP (Dupont) to a specific activity of approximately $4 \times 10^{8}$ c.p.m./ $\mu \mathrm{g}$ using Multiprime Labeling Kit (Amersham) or with FITC-labeled dNTPs using DNA Colour Kit (Amersham). Fresh-frozen (non-radioactive analysis) and fixed sections (radioactive analysis) were rehydrated for $10 \mathrm{~min}$ in $10 \mathrm{mM}$ PBS containing $5 \mathrm{mM} \mathrm{MgCl}_{2}$. Fresh-frozen tissue was fixed for $20 \mathrm{~min}$ in $4 \%$ paraformaldehyde in $10 \mathrm{mM}$ PBS. Sections designated as negative controls were rinsed briefly in $2 \times S S C$ and incubated for $1 \mathrm{~h}$ at $37^{\circ} \mathrm{C}$ with $100 \mu \mathrm{l}$ RNase A $(100 \mu \mathrm{g} / \mathrm{ml})$. Experimental slides were maintained in fresh $10 \mathrm{mM} \mathrm{PBS}$ and $5 \mathrm{mM} \mathrm{MgCl}_{2}$ for $1 \mathrm{~h}$ at $37^{\circ} \mathrm{C}$. For radioactive analysis, sections were rinsed five times in $10 \mathrm{mM}$ PBS with $10 \mathrm{mM}$ DTT for 2 min per wash, two times in $1 \times \mathrm{SSC}$ with $10 \mathrm{mM}$ DTT for 5 min per wash, and prehybridized for $1 \mathrm{~h}$ at room temperature in $40 \mu \mathrm{l} 50 \%$ formamide, $1 \times \mathrm{SSC}, 0.4 \% \mathrm{BSA}, 20 \mathrm{mM}$ DTT, $20 \mathrm{mM}$ 
vanadyl-ribonucleoside complex, $10 \mu \mathrm{g} / \mathrm{ml}$ yeast tRNA (heat-denatured), and $200 \mu \mathrm{g} / \mathrm{ml}$ salmon testes DNA (heat-denatured). Hybridization was performed at $44^{\circ} \mathrm{C}$ overnight in $40 \mu \mathrm{l}$ of prehybridization solution supplemented with $10 \%$ dextran sulfate and ${ }^{35} \mathrm{~S}$-labeled probe. Sections were washed twice in $50 \%$ formamide, $1 \times \mathrm{SSC}$, and $10 \mathrm{mM}$ DTT at $50^{\circ} \mathrm{C}$ for $30 \mathrm{~min}$ per wash, three times in $50 \%$ formamide, once in $1 \times \mathrm{SSC}, 10 \mathrm{mM}$ DTT at $44^{\circ} \mathrm{C}$ for $20 \mathrm{~min}$, and three times in $0.5 \times \mathrm{SSC}$ with $10 \mathrm{mM}$ DTT at room temperature for 20 min per wash. Sections were dehydrated through progressively higher concentrations of ethanol. Slides were dipped in NBT-2 nuclear-track photographic emulsion (Kodak) and exposed for 14 days at $4{ }^{\circ} \mathrm{C}$. Autoradiograms were developed by incubating slides for $5 \mathrm{~min}$ in Kodak D-19 developer, $30 \mathrm{~s}$ in 2\% acetic acid, $5 \mathrm{~min}$ in $30 \%$ sodium thiosulphate, and $30 \mathrm{~min}$ in running water. Sections were lightly counterstained with $\mathrm{H} / \mathrm{E}$. For non-radioactive analysis, sections were incubated successively in $20 \mathrm{mM} \mathrm{HCl}$ for 10 min at room temperature, in $10 \mathrm{mM}$ PBS containing $0.1 \%$ Triton- $X$ for $90 \mathrm{~s}$ at $4{ }^{\circ} \mathrm{C}$, and in cold $20 \%$ glacial acetic acid for $15 \mathrm{~s}$ at $4{ }^{\circ} \mathrm{C}$. Sections were rinsed in PBS between incubations. Denatured FITC-labeled probe was added to hybridization buffer (Amersham) diluted 1:1 with deionized formamide and sections were heated for $1 \mathrm{~min}$ at $90^{\circ} \mathrm{C}$ before incubation at $42^{\circ} \mathrm{C}$ overnight. Following hybridization, sections were washed twice in $1 \times$ SSC containing $0.1 \%$ SDS and twice in $0.2 \times$ SSC containing $0.1 \%$ SDS at $42^{\circ} \mathrm{C}$ for $5 \mathrm{~min}$ with shaking Sections were rinsed in PBS and exposed to peroxidase anti-FITC (1: 1000, Boehringer Mannheim) in 10 mM PBS containing 3\% BSA for $1 \mathrm{~h}$ at room temperature. Probe binding was visualized colorimetrically by incubation in $1 \mathrm{mg} / \mathrm{ml}$ diaminobenzidine in $50 \mathrm{mM}$ Tris- $\mathrm{HCl}$ containing $0.003 \% \mathrm{H}_{2} \mathrm{O}_{2}$. In some cases, sections were lightly counterstained with $\mathrm{H} / \mathrm{E}$. Slides were dehydrated and coverslipped with Permount (Fisher). The total number of $\mathrm{H} / \mathrm{E}$-stained $\mathrm{CA} 3 \mathrm{C}$ neurons and the number of neurons exhibiting non-radioactive PAFR in situ hybridization in dorsal hippocampus from sections at bregma -4.6 were counted at $250 \times$ magnification by light microscopy. Counts were averaged over two adjacent sections per animal.

\section{Reactive gliosis}

Activated astrocytes were identified by immunoreactivity with a monoclonal mouse anti-GFAP antibody (1:40; Boehringer Mannheim). Sections were incubated with primary antibody overnight at $4^{\circ} \mathrm{C}$, washed with $10 \mathrm{mM}$ PBS, and reacted for $30 \mathrm{~min}$ at $37^{\circ} \mathrm{C}$ with FITC-labeled or Texas-Red labeled goat anti-mouse IgG antibodies (1:20 and 1:40 respectively; Amersham). Both primary and secondary antibodies were diluted in Ab buffer (10 mM PBS, $0.3 \%$ Triton X-100, 3\% BSA). Sections were coverslipped under glycerol containing $0.1 \% p$-phenylenediamine (Sigma). To assess specificity of immunoreaction, adjacent sections were processed as described above but in the presence of primary antibody.

\section{In situ detection of apoptotic cells}

Apoptotic cells were identified by evaluation of cell ultrastructure following hemotoxylin and eosin $(\mathrm{H} / \mathrm{E})$ staining and by biochemical analysis of terminal deoxynucleotidyl transferase (TdT)-mediated dUTP nick end labeling (TUNEL) of DNA strand breaks. H/E stained cells with oval nuclei and prominent nucleoli without eosinophilic cytoplasm were considered to be normal and healthy. Pyknotic cells with multiple eosinophilic inclusions and amorphous nuclei were defined as apoptotic cells. Swollen or membrane-compromised neurons with dense, ubiquitous eosinophilic staining of cell cytoplasm or spillage of eosinophilic and hyperchromatic cell cytoplasm into extracellular space were defined as necrotic. Sections $(10 \mu \mathrm{m})$ reacted for TUNEL were permeabilized by a 15 min incubation in $0.1 \%$ Triton $\mathrm{X} / 0.1 \%$ sodium citrate on ice. Sections were rinsed for $2 \mathrm{~min}$ in $10 \mathrm{mM}$ PBS on ice prior to reaction FITC-labeled dUTP in TDT buffer $(30 \mathrm{mM}$ Tris- $\mathrm{HCl}, \mathrm{pH} 7.2,140 \mathrm{mM}$ sodium cacodylate, $1 \mathrm{mM}$ cobalt chloride) and TdT. Labeling was carried out according to the protocol supplied by the manufacturer (Boehringer Mannheim). Sections were coverslipped under glycerol containing $0.1 \%$ p-phenylenediamine (Sigma) and labeling assessed by immunofluorescence. Negative controls included sections incubated with FITC-labeled dUTP in the absence of TdT. In some cases, fresh-frozen sections were processed for nonradioactive PAFR in situ hybridization prior to TUNEL or reacted with anti-GFAP following TUNEL. The total number of CA3c TUNELpositive neurons were counted as described above under fluorescent microscopy. Counts were averaged over two adjacent sections per animal.

\section{Acknowledgements}

These studies were supported in part by grants from the Alzheimer Society of Canada to SALB, the National Sciences and Engineering Research Council and the Ontario Heart and Stroke Foundation of Ontario to BAP, the Medical Research Council of Canada to DCSR, and the National Institute of Health (\#RO1CA69233-01) to MT. We gratefully acknowledge Dr. N. Gerard for providing the pCDM8/PAFR plasmid and Jim Bennett for excellent technical and critical assistance.

\section{References}

Bazan NG, Zorumski CF and Clark GD (1993) The activation of phospholipase $A_{2}$ and release of arachidonic acid and other lipid mediators at the synapse: The role of platelet-activating factor. J. Lipid Mediat. 6: 421-427

Ben-Ari $Y$ (1993) The role of seizures in kainic acid induced brain damage. In: Excitotoxins: Wenner Gren International Symposium (Fuxe K, Roberts P, Schwartz R eds), pp 184-198. London: Macmillan Press

Bennett SAL, Leite LCC and Birnboim HC (1993) Platelet activating factor, an endogenous mediator of inflammation, induces phenotypic transformation of rat embryo cells. Carcinogenesis 14: 1289-1296

Bennett SAL, Stevenson B, Staines WA and Roberts DCS (1995) Periodic acidSchiff(PAS)-positive deposits in brain following kainic acid-induced seizures: Relationships to fos induction, neuronal necrosis, reactive gliosis, and bloodbrain barrier breakdown. Acta Neuropathol. 89: 126-138

Bennett SAL, Tenniswood M, Chen J-H, Davidson CM, Keyes MT, Fortin T and Pappas BA (1998) Chronic cerebral hypoperfusion elicits neuronal apoptosis and behavioral impairment. Neuroreport 9: 161-166

Beusenberg FD, Bonta IL and Van Amsterdam JGC (1994) Cyclic-AMP level and eicosanoid release from alveolar macrophages are differentially affected by high and low dose of platelet activating factor. Biochem. Pharmacol. 47: 588-590

Bito H, Nakamura M, Honda Z, Izumi T, Iwatsubo T, Seyama Y, Ogura A, Kudo Y and Shimizu T (1992) Platelet-activating factor (PAF) receptor in rat brain: PAF mobilizes intracellular $\mathrm{Ca}^{2+}$ in hippocampal neurons. Neuron 9: 285-294

Bito H, Honda Z, Nakamura M and Shimizu T (1994) Cloning, expression and tissue distribution of rat platelet-activating-factor-receptor CDNA. Eur. J. Biochem. 221: 211-218

Bonavida B and Mencia-Huerta JM (1994) Platelet-activating factor and the cytokine network in inflammatory processes. Clin. Rev. Allergy 12: 381-395

Boschert U, Muda M, Camps M, Dickinson R and Arkinstall S (1997) Induction of the dual specificity phosphatase PAC1 in rat brain following seizure activity. Neuroreport 8: $3077-3080$

Braquet $\mathrm{P}$, Paubert-Braquet $\mathrm{M}$, Koltai M, Bourgain R, Bussolino F and Hosford D (1989) Is there a case for PAF antagonists in the treatment of ischemic states? TIPS 10: $23-30$

Brodie C (1994) Functional PAF receptors in glia cells: Binding parameters and regulation of expression. Int. J. Dev. Neurosci. 12: 631-640

Choi DW (1996) Ischemia-induced neuronal apoptosis. Curr. Opin. Neurobiol. 6: $667-672$ 
Dessi F, Charriaut-Marlangue C, Khrestchatisky M and Ben-Ari Y (1993) Glutamateinduced neuronal death is not a programmed cell death in cerebellar culture. J. Neurochem. 60: 1953-1955

Doly M, Cluzel J, Millerin M, Bonhomme B and Braquet P (1993) Prevention of chloroquine-induced electroretinographic damage by a new platelet-activating factor antagonist, BN 50730. Ophthalmic. Res. 25: 314-318

Domingo MT, Spinnewyn B, Chabrier PE and Braquet P (1994) Changes in [3H]PAF binding and PAF concentrations in gerbil brain after bilateral common carotid artery occlusion: A quantitative autoradiographic study. Brain Res. 640: 268276

Dragunow M, BeilharzE, Sirimanne E, Lawlor P, Williams C, Bravo Rand Gluckman P (1994) Immediate-early gene protein expression in neurons undergoing delayed death, but not necrosis, following hypoxic-ischaemic injury to the young rat brain. Brain Res. Mol. Brain Res. 25: 19-33

El Azzouzi B, Jurgens P, Benveniste J and Thomas Y (1993) Immunoregulatory functions of PAF-acether. IX. Modulation of apoptosis in an immature T cell line. Biochem. Biophys. Res. Commun. 190: 320-324

Ferraris L, Karmeli F, Eliakim R, Klein J, Fiocchi C and Rachmilewitz D (1993) Intestinal epithelial cells contribute to the enhanced generation of platelet activating factor in ulcerative colitis. Gut 34: 665-668

Feurstein G, Yue G and Lysko R (1990) Platelet activating factor: a putative mediator in central nervous system injury? Stroke 21 (suppl III): III-90-III-94

Gavrieli Y, Sherman Y and Ben-Sasson AJ (1992) Identification of programmed cell death in situ via specific labeling of nuclear DNA fragmentation. J. Cell Biol. 119: 493-501

Gelbard HA, Nottet HSLM, Swindells S, Jett M, Dzenko KA, Genis P, White R, Wang L, Choi Y-B, Zhang D, Lipton SA, Tourtellotte WW, Epstein LG and Gendelman $\mathrm{HE}$ (1994) Platelet-activating factor: a candidate human immunodeficiency virus type 1-induced neurotoxin. J. Virol. 68: 4628-4635

Giulian D, Li J, LiX, George J and Rutecki PA (1994) The impact of microglia-derived cytokines upon gliosis in the CNS. Dev. Neurosci. 16: 128-136

Graham RM, Strahan ME, Norman KW, Watkins DN, Sturm MJ and Taylor RR (1994) Platelet and plasma platelet-activating factor in sepsis and myocardial infarction. J. Lipid Mediat. 9: 167-182

HondaZ, Nakamura M, Miki M, Minami M, Watanabe T, Seyma Y, Okado H, Toh H, Ito K, Miyamoto Mand Shimizu T (1991) Cloning by functional expression of plateletactivating factor receptor from guinea-pig lung. Nature 349: $342-345$

Ikeda J, TerakawaS, MurotaS, Morita I and Hirakawa K(1996) Nuclear disintegration as a leading step of glutamate excitotoxicity in brain neurons. J. Neurosci. Res. 43: $613-622$

Kalaria RN (1993) The immunopathology of Alzheimer's disease and some related disorders. Pathology 13367: 12336-13105

Kornecki E and Ehrlich YH (1988) Neurology and neuropathological actions of the ether-phospholipid platelet activating factor. Science 240: 1792-1794

Kumar R, Harvey S, Kester N, Hanahan D and Olson M (1988) Production and effects of platelet-activating factor in the rat brain. Biochem. Biophys. Acta 963: $375-$ 383

Kunz D, Gerard NP and Gerard C (1992) The human leukocyte platelet-activating factor receptor. cDNA cloning, cell surface expression, and construction of a novel epitope-bearing analog. J. Biol. Chem. 267: 9101-9106

Lassman H, Petsche U, Kitz K, Baran H, Sperk G, Seitelberger F and Hornikiewitz O (1994) The role of brain edema on epileptic brain damage induced by systemic kainic acid injection. Neuroscience 13: 671-704

Lustig HS, Chan J and Greenberg DA (1992) Comparative neurotoxic potential of glutamate, endothelins, and platelet-activating factor in cerebral cortical cultures. Neurosci. Lett. 139: 15-18

Majno $G$ and Joris I (1995) Apoptosis, oncosis, and necrosis: An overview of cell death. Am. J. Pathol. 146: 3-15

Marcheselli VL and Bazan NG (1993) Platelet activating factor (PAF) enhances glutamic acid release in the retina through a presynaptic receptor. Invest Ophthalmol. Vis. Sci. 34 (suppl): 1048

Marcheselli VL and Bazan NG (1994) Platelet-activating factor is a messenger in the electroconvulsive shock-induced transcriptional activation of c-fos and zif-268 in hippocampus. J. Neurosci. Res. 37: 54-61
McIntyre DC, Nathanson D and Edson N (1982) A new model for partial status epilepticus based on kindling. Brain Res. 250: 53-63

Mori M, Aihara M, Kume K, Hamanoue M, Kohsaka S and Shimizu T (1996) Predominant expression of platelet-activating factor receptor in rat brain microglia. J. Neurosci. 16: 3590-3600

Nitatori T, Sato N, Waguri S, Karasawa Y, Araki H, Shibanai K, Kominami E and Uchiyama Y (1995) Delayed neuronal death in the CA1 pyramidal cell layer of the gerbil hippocampus following transient ischemia is apoptosis. J. Neurosci. 15: $1001-1011$

Petroni A, Salami M, Blasevich M, Papini N, Galella G, Colombo C and Galli C (1994) Eicosanoid and inositol phosphate response to platelet-activating factor (PAF) and to a PAF antagonist in rat astroglial cells. Dev. Brain Res. 78: 169-174

Piechaczyk M, Blanchard JM, Marty L, Dani C, Panabieres F, Sabouty SE, Fort P and Jeanteur P (1984) Post-transcriptional regulation of glyceraldehyde-3phosphate-dehydrogenase gene expression in rat tissues. Nucleic Acids Res. 12: $6951-6963$

Pollard H, Cantagrel S, Charriaut-Marlangue C, Moreau J and Ben-Ari Y (1994) Apoptosis associated DNA fragmentation in epileptic brain damage. Neuroreport 5: $1053-1055$

Portera-Cailliau C, Hedreen JC, Price DL and Koliatsos VE (1995) Evidence for apoptotic cell death in Huntington Disease and Excitotoxic Animal Models. J. Neurosci. 15: $3775-3787$

Sakhi S, Sun N, Wing LL, Mehtu P and Schreiber SS (1996) Nuclear accumulation of p53 protein following kainic acid-induced seizures. Neuroreport 7: 493-496

Smeyne RJ, Vendrell M, Hayward M, Baker SJ, Miao GG, Schilling K, Robertson LM, Curran T and Morgan JI (1993) Continuous c-fos expression precedes programed cell death in vivo. Nature 363: 166-169

Sobhani I, Hochlaf S, Denizot Y, Vissuzaine C, Rene E, Benveniste J, Lewin MMJ and Mignon M (1992) Raised concentrations of platelet activating factor in colonic mucosa of Crohn's disease patients. Gut 33: 1220-1225

Squinto SP, Block AL, Braquet P and Bazan NG (1989) Platelet-activating factor stimulates a fos/jun/AP-1 transcriptional signalling system in human neuroblastoma cells. J. Neurosci. 24: 558-566

Steinberg RA, Figlewicz DA, MacDonald ME, Greenamyre T, Hamill R, Shoulson and Powers JM (1996) Coexistence of Huntington's disease and familia amyotrophic lateral sclerosis: case presentation. Acta Neuropathol. 92: 421 427

Sugimoto T, Tsuchimochi H, McGregor CGA, Mutoh H, Shimizu T and Kurachi $Y$ (1992) Molecular cloning and characterization of the platelet-activating factor receptor gene expressed in the human heart. Biochem. Biophys. Res. Commun. 189: $617-624$

Szaflarski J, Burtrum D and Silverstein FS (1995) Cerebral hypoxia-ischemia stimulates cytokine gene expression in perinatal rats. Stroke 26: 1093-1100

Taniwaki Y, Araki T, Kobayashi T and Kato M (1996) Microglial activation during kainic acid-induced hippocampal seizures in the rat. Epilepsia 37 Suppl3:64-65

van Lookeren Campagne M, Lucassen PJ, Vermeulen JP and Balazs R (1995) NMDA and kainate induce internucleosomal DNA cleavage associated with both apoptotic and necrotic cell death in the neonatal rat brain. Eur. J. Neurosci. 7: $1627-1640$

Yamamoto H, Nagata M, Tabe K, Kimura I, Kiuchi H, Sakamoto Y, Yamamoto Kand Dohi Y (1993) The evidence of platelet activation in bronchial asthma. J. Allergy Clin. Immunol. 91: 79-87

Ye R, Prossnitz E, Zou A and Cochrane C (1991) Characterization of a human cDNA that encodes a functional receptor for platelet-activating factor. Biochem. Biophys. Res. Commun. 180: 105-111

Yue T-L, Gu J-L and Feuerstein G (1992) Protein kinase C activator phorbol 12,13dibutyrate inhibits platelet activating factor-stimulated $\mathrm{Ca}^{2+}$ mobilization and phosphoinositide turnover in neurohybrid NG108-15 cells. Neurochem. Res. 17 997-1004 